\title{
DEVELOMENT OF INTEGRATION PROCESSES IN THE GLOBALIZATION CONDITIONS: UKRAINE AND EU-COUNTRIES
}

\author{
Dariia Babenko \\ Department of International Economics and \\ Management of Foreign Economic Activity \\ Simon Kuznets Kharkiv National University of Economics \\ Nauki ave., 9-A, Kharkiv, 61166, Ukraine \\ e-mail: dary.babenko@gmail.com \\ ORCID: 0000-0002-3154-1622 \\ Zaitseva Anna \\ PhD in Economics \\ International Economic Relations named after Arthur Golikov \\ V.N. Karazin Kharkiv National University \\ Svobody sq., 4, Kharkiv, 61022, Ukraine \\ e-mail: glazkova@karazin.ua \\ ORCID: 0000-0003-0818-7853 \\ Kateryna Velychko \\ PhD in Economics, Associate Professor \\ Department of International Economics and \\ Management of Foreign Economic Activity \\ Simon Kuznets Kharkiv National University of Economics \\ Nauki ave., 9-A, Kharkiv, 61166, Ukraine \\ e-mail: eklevyna@gmail.com \\ ORCID: 0000-0002-7751-585X
}

\begin{abstract}
The change in Ukraine's position, taking into account various approaches to assessing the development of integration processes, indicates the importance of choosing the forecast for the development of integration with EU member states. The subject of the study is integration with the EU member states. The aim of the article is to analyze the development of integration processes in Ukraine and the EU member states, build a forecast of the strategy of international integration on the example of Ukraine and the EU countries in the context of globalization. Research methods: the method of multivariate statistical analysis, namely factor analysis to determine the factors affecting the development of integration processes; modeling of growth curves for predicting the values of indicators of integration processes. The calculations were performed using the Statgraphics Centurion application package. Based on the results of the research, a basis of indicators characterizing the socio-economic situation of the member countries of the integration processes is formed. It included: GDP and GDP per capita, attracting foreign direct investment and consumer price indices; as well as the share of ICT goods. The analysis of problems and prospects for the development of integration processes on the basis of a theoretical and logical analysis taking into account the strategic directions of development of the Ukrainian economy and the world economy is carried out. The forecast indicators for the member countries of the EU group and Ukraine are calculated. This allowed us to develop forecast scenarios for the development of integration processes of the member countries of integration processes in the long term. Based on the forecast obtained, strategic positions of Ukraine and the EU member states in the global integration space for three forecasting periods are formed. Conclusions: priority scenarios for the development of the integration processes of these EU member states are identified, namely Czech Republic, Estonia, Latvia, Lithuania, Poland and Ukraine indicate a positive prospect of EU cooperation with Ukraine in the aspect of international integration.

Keywords: EU countries, globalization, integration processes, international economic relations, integration development scenarios, factor analysis, growth curves, forecasting.
\end{abstract}

\section{Introduction.}

The socio-economic and political processes taking place in Ukraine require the government to introduce new approaches to integration into the international integration space. This is especially true for the choice of the integration vector, in particular based on the choice of scenarios for the development of integration processes with the EU.

The emergence of the EU was aimed at creating a common market and, on this basis, improving economic stability and living standards. The EU agreement defined a sequence of measures to achieve this goal: the abolition of duties, import and export quantitative restrictions on the movement of goods within the community; the introduction of a common customs tariff and a single trade policy for third countries; ensuring the free movement of factors of production, the freedom to create branches in the EU and free trade in services between member countries; pursuing a common agricultural and transport policy; creating conditions for competition within the community; coordination and gradual approximation of economic policies of member countries; alignment of domestic legal norms relevant to the common market.

Changing the position of countries, taking into account different approaches to assessing the development of integration processes, which provides a characteristic of the socio-economic situation of these countries, indicates the importance of choosing basic indicators for assessing the development of regional integration, is an urgent issue of our time. 
Currently, a lot of scientists are paying considerable attention to the study of integration processes in the global economy, their role in the globalization of world economic relations in accordance with the laws of development of international integration. Of particular relevance is the issue of forecasting and managing these processes using mathematical tools. So, A.M. Dubrova, V.S. Mkhitaryan, L.I. Troshin [1] are interested in the applied aspect of economic and mathematical modeling of world economic and integration processes. In the works of V.S. Ponomarenko and L. Malyarets [2], [3] study the measurement of features of objects in the economy and analyze data, use multivariate statistical methods, as well as [4] - [6]. The subject of forecasting the results of integration processes is devoted to the work of A.Yu. Michurin [7], the problems of developing and constructing integration scenarios are disclosed in their works by A.M. Anisimov [8] and I.N. Burganova [9].

Despite the depth of modern scientific research on this issue, some practical aspects require further study and clarification, because under the conditions of the influence of global economic changes and the transformation of the world order, the issue of forecasting an international integration strategy becomes especially urgent and creates the basis for decision-making on the choice of the vector of foreign economic activity of Ukraine.

Materials and methods.

To determine the factors influencing the development of integration processes, one should use the method of multivariate statistical analysis factor analysis [1]. This analysis is intended to identify and quantify the generalizing characteristics that are latent factors and sufficiently describe the entire set of initial and resulting indicators. The calculations are carried out on the example of the member countries of the EU integration association. To determine the latent factors in each component that characterize the socio-economic development of the EU countries in the global integration space, the Statgraphics Centurion statistical package was used [1].

To develop the forecast, we apply forecast models, namely - growth curves [1]. To predict the values of indicators of regional integration processes, the Statgraphics Centurion application package will be used.

\section{Results and discussion.}

The theoretical and logical analysis of scientific literary sources, formed methodological approaches to assessing the effectiveness of regional integration processes made it possible to determine the main components of integration processes, which are characterized by macroeconomic indicators of the socio-economic status of member countries of integration associations. So, we have obtained a system of macroeconomic indicators for analyzing problems and prospects for the development of regional integration processes, which consists of 6 private indicators (Table 1).

A feature of this system of indicators is its structuring according to the main components characterizing the socio-economic situation of the countries-members of integration processes:

- component characterizing the finances of countries;

- compound on foreign economic relations of countries participating in integration processes;

- component reflecting the level of economic potential of the country;

- component reflecting the development of information technology in the country.

Namely: GDP and GDP per capita, attracting foreign direct investment and consumer price indices; as well as the share of ICT goods.

Consider the statistics for the last five years, these indicators. Consider several EU member states (Table 2).

Table 1

The list of indicators characterizing the socio-economic situation of member countries of regional integration processes

\begin{tabular}{|c|c|c|c|}
\hline № & Indicator & Symbol index & Units \\
\hline \multicolumn{4}{|c|}{ Component of national accounts indicators } \\
\hline 1. & $\begin{array}{c}\text { GDP } \\
\text { annual average growth rate }\end{array}$ & $y_{1}$ & $\%$ to the previous year \\
\hline 2. & $\begin{array}{l}\text { Gross domestic product, annual average } \\
\text { growth rate per capita }\end{array}$ & $y_{2}$ & \\
\hline 3. & Consumer price indices & $y_{3}$ & $\%$ to the previous year \\
\hline 4. & $\begin{array}{c}\text { Share of ICT goods as percentage of total } \\
\text { trade, imports }\end{array}$ & $y_{4}$ & $\%$ \\
\hline 5. & $\begin{array}{l}\text { Share of ICT goods as percentage of total } \\
\text { trade, exports }\end{array}$ & $y_{5}$ & $\%$ \\
\hline 6. & Foreign direct investment & $\mathrm{y}_{6}$ & million US dollars \\
\hline
\end{tabular}

[compiled by the author according to [10]-[14]] 
The values of the indicators of socio-economic development of the EU and Ukraine for the period 2014-2018.

\begin{tabular}{|c|c|c|c|c|c|}
\hline \multicolumn{6}{|c|}{ Gross domestic product, annual average growth rate } \\
\hline & 2014 & 2015 & 2016 & 2017 & 2018 \\
\hline $\begin{array}{c}\text { Czech } \\
\text { Republic }\end{array}$ & 2,72 & 5,31 & 2,45 & 4,29 & 2,88 \\
\hline Estonia & 2,89 & 1,67 & 2,06 & 4,85 & 3,90 \\
\hline Latvia & 1,86 & 2,97 & 2,06 & 4,64 & 4,80 \\
\hline Lithuania & 3,54 & 2,02 & 2,35 & 4,14 & 3,35 \\
\hline Poland & 3,32 & 3,84 & 3,06 & 4,81 & 5,10 \\
\hline Ukraine & $-6,55$ & $-9,77$ & 2,44 & 2,52 & 3,30 \\
\hline \multicolumn{6}{|c|}{ Gross domestic product, annual average growth rate per capita } \\
\hline & 2014 & 2015 & 2016 & 2017 & 2018 \\
\hline $\begin{array}{c}\text { Czech } \\
\text { Republic }\end{array}$ & 2,67 & 5,21 & 2,28 & 4,07 & 2,64 \\
\hline Estonia & 3,11 & 1,75 & 1,97 & 4,63 & 3,62 \\
\hline Latvia & 3,05 & 4,19 & 3,27 & 5,88 & 6,03 \\
\hline Lithuania & 4,84 & 3,40 & 3,85 & 5,76 & 4,98 \\
\hline Poland & 3,50 & 3,99 & 3,18 & 4,91 & 5,19 \\
\hline Ukraine & $-6,19$ & $-9,39$ & 2,92 & 3,05 & 3,86 \\
\hline \multicolumn{6}{|c|}{ Share of ICT goods as percentage of total trade, imports } \\
\hline & 2014 & 2015 & 2016 & 2017 & 2018 \\
\hline $\begin{array}{c}\text { Czech } \\
\text { Republic }\end{array}$ & 14,11 & 15,63 & 14,24 & 15,33 & 16,45 \\
\hline Estonia & 11,50 & 11,21 & 11,53 & 9,41 & 9,87 \\
\hline Latvia & 8,95 & 10,18 & 10,05 & 9,34 & 9,98 \\
\hline Lithuania & 4,07 & 5,10 & 5,51 & 5,76 & 5,8 \\
\hline Poland & 8,88 & 9,79 & 9,24 & 9,06 & 9,09 \\
\hline Ukraine & 3,56 & 4,01 & 4,88 & 5,13 & 5,23 \\
\hline \multicolumn{6}{|c|}{ Share of ICT goods as percentage of total trade, exports } \\
\hline & 2014 & 2015 & 2016 & 2017 & 2018 \\
\hline $\begin{array}{c}\text { Czech } \\
\text { Republic }\end{array}$ & 13,42 & 13,54 & 12,72 & 13,33 & 13,48 \\
\hline Estonia & 12,80 & 11,91 & 12,53 & 9,28 & 10,3 \\
\hline Latvia & 9,80 & 11,52 & 10,50 & 9,34 & 10,1 \\
\hline Lithuania & 2,94 & 3,95 & 3,86 & 4,08 & 4,34 \\
\hline Poland & 7,74 & 8,12 & 7,14 & 6,92 & 7,1 \\
\hline Ukraine & 0,96 & 0,82 & 0,95 & 0,93 & 0,96 \\
\hline \multicolumn{6}{|c|}{ Consumer price indices, annual } \\
\hline & 2014 & 2015 & 2016 & 2017 & 2018 \\
\hline $\begin{array}{c}\text { Czech } \\
\text { Republic }\end{array}$ & 0,34 & 0,31 & 0,68 & 2,45 & 2,55 \\
\hline Estonia & $-0,11$ & $-0,49$ & 0,15 & 3,42 & 3,40 \\
\hline Latvia & 0,62 & 0,17 & 0,14 & 2,93 & 2,74 \\
\hline Lithuania & 0,10 & $-0,88$ & 0,91 & 3,72 & 3,78 \\
\hline Poland & 0,05 & $-0,87$ & $-0,66$ & 2,08 & 2,08 \\
\hline Ukraine & 12,07 & 48,70 & 13,91 & 14,44 & 14,56 \\
\hline \multicolumn{6}{|c|}{ Foreign direct investment: Inward and outward flows and stock, annual } \\
\hline & 2014 & 2015 & 2016 & 2017 & 2018 \\
\hline $\begin{array}{c}\text { Czech } \\
\text { Republic }\end{array}$ & 5492,00 & 465,10 & 9814,77 & 9521,68 & 9478,89 \\
\hline Estonia & 684,46 & 35,60 & 1095,75 & 1712,19 & 1309,36 \\
\hline Latvia & 780,12 & 707,58 & 173,66 & 732,48 & 879,38 \\
\hline Lithuania & $-23,32$ & 870,35 & 263,88 & 652,29 & 905,07 \\
\hline Poland & 14268,74 & 15270,83 & 15690,15 & 9178,51 & 11476,25 \\
\hline Ukraine & 410,00 & 2961,00 & 3284,00 & 2601,00 & 2355,00 \\
\hline
\end{tabular}

[compiled by author]

10 
Based on the calculations of factor analysis, it is advisable to compile a rating of the impact of each of the obtained 6 independent indicators characterizing the integration processes and identify the most significant of them. This made it possible to obtain the most influential indicator (latent factor), with the help of which they formulate strategies for the development of regional integration processes of EU member states:

$$
\begin{gathered}
F=0,451 y_{1}+0,5002 y_{2}-0,553 y_{3}+0,4099 y_{4}+ \\
0,614 y_{5}+0,4785 y_{6}
\end{gathered}
$$

A certain latent factor in the development of integration processes should be taken as a basis for forecasting and building strategies for the development of integration processes.

To develop a forecast, we apply growth curves (forecast models) [1]. Using a system of certain indicators, based on data for the period 2014-2018, an equation of growth curves is obtained for forecasting the values of the Czech Republic indicators and the forecast values of the most influential indicators for a three-year perspective period for the Czech Republic are calculated (Table 3).

Predicted values of indicators of regional integration processes in Czech Republic (for the period 2020-2022)

\begin{tabular}{|c|c|c|c|}
\hline Indicators & $\begin{array}{c}\text { The first forecasting } \\
\text { period }\end{array}$ & $\begin{array}{c}\text { The second forecasting } \\
\text { period }\end{array}$ & $\begin{array}{c}\text { The third forecasting } \\
\text { period }\end{array}$ \\
\hline$y_{1}$ & 3,721 & 4,317 & 4,907 \\
\hline$y_{2}$ & 2,936 & 3,036, & 3133 \\
\hline$y_{3}$ & 2,608 & 2,613 & 2,623 \\
\hline$y_{4}$ & 3,967 & 3,964 & 3,962 \\
\hline$y_{5}$ & 6,060 & 6,161 & 6,251 \\
\hline$y_{6}$ & 219,4 & 221,9 & 224,5 \\
\hline
\end{tabular}

[author's calculations]

Similarly, the equation of growth curves was found for forecasting indicator values for Estonia, Lithuania, Latvia and Poland, and the forecast values of indicators characterizing the development of world integration for these countries over a three-year forecasting period were found.

To determine the level of development of regional integration processes in the EU during 2014-2018, it is necessary to calculate the integral indicators for each country from this association using the method of constructing a taxonomic indicator of the development of dynamic socio-economic processes V. Plyuta [3]. A characteristic property of the integral indicator is that its value is in the range from 0 to 1 . The interpretation of this indicator is as follows: it takes on high values at close values of indicators in the system to the reference and low values at distant ones [1].

For a comparative analysis of the socio-economic development of Ukraine with the EU member states, growth curves should be calculated to find the values of forecast indicators - components of an integral indicator for Ukraine.

$\mathrm{y}_{1}=\operatorname{sqrt}(135959-61180,4 \ln (t))$

$R^{2}=87,2807, F=61,76, D W=1,0037$

$\mathrm{y}_{2}=1 /(0,000044+0,000051 / t)$

$R^{2}=60,6004, F=13,84, D W=2,6129$

$y_{3}=\exp (7,6865+0,6074 \operatorname{sqrt}(t))$

$R^{2}=93,8207, F=136,65, D W=3,0758$

$\mathrm{y}_{4}=(44,8133+14,7625 \mathrm{sqrt}(t))^{2}$

$R^{2}=86,7539, F=58,94, D W=2,40329$

$\mathrm{y}_{5}=\operatorname{sqrt}\left(2,6558-377205 t^{2}\right)$

$R^{2}=1,72207, F=0,16, D W=1,7633$

$\mathrm{y}_{6}=1,894-0,6622 t$

$R^{2}=65,2175, F=16,88, D W=1,7669$

All models have relative quality.

Based on the obtained equations, it is necessary to calculate the predicted values for each resulting indicator characterizing the integration processes of Ukraine (Table 3).

Table 3

Predicted values of indicators of regional integration processes in Ukraine (for the period 2020-2022)

\begin{tabular}{|c|c|c|c|}
\hline Indicators & $\begin{array}{c}\text { The first forecasting } \\
\text { period }\end{array}$ & $\begin{array}{c}\text { The second forecasting } \\
\text { period }\end{array}$ & $\begin{array}{c}\text { The third forecasting } \\
\text { period }\end{array}$ \\
\hline$y_{1}$ & 3,273 & 3,505 & 3,721 \\
\hline$y_{2}$ & 4,130 & 3,341 & 2,508 \\
\hline$y_{3}$ & 1,239 & 1,305 & 1,378 \\
\hline$y_{5}$ & 3,329 & 3,143 & 3,996 \\
\hline$y_{6}$ & 0,263 & 1,123 & 1,473 \\
\hline$y_{7}$ & 208,281 & 209,712 & 210,954 \\
\hline
\end{tabular}

[author's calculations] 
With the help of the calculations, it is possible to obtain a forecast of the development scenarios of Ukraine and the member countries of the EU association in the global integration space. The positions of countries are determined in the space of the resulting. The space should be conditionally divided into four sectors. Each represents a scenario of strategic development in the context of the development of integration processes.

Thus, it is advisable to consider four scenarios of the development of countries in the aspect of integration processes. It is proposed to present the strategic positioning of Ukraine and the EU member states in the form of a matrix of scenarios for the development of regional integration processes, which contains four positions (scenarios) of strategic development in the aspect of regional integration processes: I - low strategic position, II and III medium strategic position and IV - high strategic position.

According to the first scenario, countries with the lowest values of the resulting integral indicator, namely, GDP per capita with the minimum values of particular indicators, should be considered. In the second scenario, the positions of countries are characterized by high values of the integral indicator with minimal values of particular indicators. According to the third scenario, low values of the integral indicator are provided with sufficient values of particular indicators. The fourth development scenario includes countries with high values of the integral indicator with significant values of private indicators.

\section{Conclusion.}

Based on the forecast for the development scenarios of the EU and Ukraine in the global integration space, we can determine the priority scenarios for the development of international cooperation with the countries of the EU integration association. Thus, a steady trend is observed for indicators characterizing regional integration processes in the international economic space in all forecast periods. Poland is the most distant country from Ukraine. In the first prospective forecasting period, Ukraine is expected to have the least resource-intensive international cooperation with the Czech Republic, in the second Czech with the Czech Republic and Estonia, in the third also with the Czech Republic and Estonia, but with additional costs compared to the first period.

Thus, a basis of the resulting indicators has been formed for analyzing problems and prospects for the development of regional integration processes on the basis of a theoretical analysis taking into account the strategic directions of the development of the domestic economy and the world economy, creates the basis for a comprehensive detailed analysis and makes it possible to justify strategic decisions in the formation of countries - unite in the system of world integration, increase their efficiency and effectiveness.

Based on the calculated models of the dependencies of the resulting indicators on the most significant generalizing factors characterizing the regional integration processes from 2014-2018. It is advisable to calculate the integrated indicators for the countries of the EU integration union, it makes it possible to find comparative estimates of the development of countries in the processes of global integration in dynamics and to develop scenarios for predicting the development of the countries of integration processes in the future for three forecast periods (2020 - 2022).

The calculated forecasts of the development scenarios of Ukraine and the EU member states in the global integration space are a reasonable basis for identifying priority scenarios of their development in the aspect of regional integration.

\section{РОЗВИТОК ІНТЕГРАЦІЙНИХ ПРОЦЕСІВ УКРАЇНИ ТА КРАЇН-ЧЛЕНІВ ЄС В УМОВАХ ГЛОБАЛІЗАЦІЇ}

Бабенко Дарія Сергіївна, кафедра міжнародної економіки та менеджменту зовнішньоекономічної діяльності, Харківський національний економічний університет імені Семена Кузнеця, просп. Науки, 9-А, Харків, 61166, Україна, e-mail: dary.babenko@gmail.com, ORCID: 0000-0002-3154-1622

Зайцева Анна Сергіївна, кандидат економічних наук, кафедра міжнародних економічних відносин імені Артура Голікова, Харківський національний університет імені В.Н.Каразіна, пр. Ак. Курчатова, 25, кв. 5, Харків, 61108, Україна, e-mail: glazkova@karazin.ua, ORCID: 0000-0003-0818-7853

Величко Катерина Юріївна, кандидат економічних наук, доцент, кафедра міжнародної економіки та менеджменту зовнішньоекономічної діяльності, Харківський національний економічний університет імені Семена Кузнеця, просп. Науки, 9-А, Харків, 61166, Україна, e-mail: eklevyna@gmail.com, ORCID: 0000-0002-7751-585X

Зміна позицій України з урахуванням різних підходів щодо оцінки розвитку інтеграційних процесів свідчить про важливість вибору прогнозування розвитку інтеграції з країнами-членами ЄС. Предметом дослідження є інтеграція з країнами-членами інтеграційного об'єднання ЄС. Метою дослідження є аналіз розвитку інтеграційних процесів України та країн-членів ЄС, побудова прогнозу стратегії міжнародної інтеграції на прикладі України та країн ЄС в умовах глобалізації. Методи дослідження: метод багатовимірного статистичного аналізу, а саме фракторний аналіз для визначення факторів, що впливають на розвиток інтеграційних процесів; моделювання кривих росту для прогнозування значень показників інтеграційних процесів. Обчислення виконано за допомогою пакета прикладних програм Statgraphics Centurion. Результати: на основі проведених досліджень сорормовано базис показників, що характеризують соціально-економічний стан країн-членів інтеграційних процесів. До нього увійшли: ВВП та ВВП на душу населення, залучення прямих іноземних інвестицій та індексів споживчих цін; а також частка товарів ІКТ. Виконано аналіз проблем та перспектив розвитку процесів інтеграції на основі теоретико-логічного аналізу з урахуванням стратегічних напрямів розвитку української економіки та світового господарства. Обчислено прогнозні показники для країн-членів групи ЄС та України. Це надало можливість розробити прогнозні сценарії розвитку процесів інтеграції країнчленів інтеграційних процесів у перспективному періоді. На основі отриманого прогнозу сформовано стратегічні позиції України та країн-членів ЄС у світовому інтеграційному просторі на три періоди прогнозування. Висновки: визначені пріоритетні сценарії розвитку інтеграційних процесів цих країн-членів ЄC, а саме Czechia, Estonia, Latvia, Lithuania, Poland та Ukraine свідчать про позитивну перспективу співробітництва ЄС з Україною у аспекті міжнародної інтеграції.

Ключові слова: країни ЄС, глобалізація, інтеграційні процеси, міжнародні економічні відносини, сценарії розвитку інтеграції, аналіз факторів, криві зростання, прогнозування. 


\section{РАЗВИТИЕ ИНТЕГРАЦИОННЫХ ПРОЦЕССОВ УКРАИНЫ И СТРАН-ЧЛЕНОВ ЕС В УСЛОВИЯХ ГЛОБАЛИЗАЦИИ}

Бабенко Дария Сергеевна, кафедра международной экономики и менеджмента внешнеэкономической деятельности, Харьковский национальный экономический университет имени Семена Кузнеца, просп. Науки, 9-А, Харьков, 61166, Украина, e-mail: dary.babenko@gmail.com, ORCID: https://orcid.org/0000-0002-3154-1622

Зайцева Анна Сергеевна, кандидат экономический наук, кафедра международных экономических отношений имени Артура Голикова, Харьковский национальный университет имени В.Н.Каразина, просп. Ак. Курчатова, 25, кв. 5, Харьков, 61108, Украина, e-mail: glazkova@karazin.ua, ORCID: https://orcid.org/0000-0003-0818-7853

Величко Екатерина Юрьевна, канд. экон. наук, доцент, кафедра международной экономики и менеджмента внешнеэкономической деятельности, Харьковский национальный экономический университет имени Семена Кузнеца, просп. Науки, 9-А, Харьков, 61166, Украина, e-mail: eklevyna@gmail.com, ORCID: https://orcid.org/0000-0002-7751-585X

Изменение позиций Украины с учетом различных подходов к оценке развития интеграционных процессов свидетельствует о важности выбора прогнозирования развития интеграции со странами-членами ЕС. Предметом исследования является интеграция со странами-членами интеграционного объединения ЕС. Целью исследования является анализ развития интеграционных процессов Украины и стран-членов ЕС, построение прогноза стратегии международной интеграции на примере Украины и стран ЕС в условиях глобализации. Методы исследования: метод многомерного статистического анализа, а именно факторный анализ для определения факторов, влияющих на развитие интеграционных процессов; моделирование кривых роста для прогнозирования значений показателей интеграционных процессов. Вычисления выполнены с помощью пакета прикладных программ Statgraphics Centurion. Результаты на основе проведенных исследований сформирован базис показателей, характеризующих социально-экономическое положение стран-членов интеграционных процессов. В него вошли: ВВП и ВВП на душу населения, привлечения прямых иностранных инвестиций и индексов потребительских цен; а также доля товаров ИКТ. Выполнен анализ проблем и перспектив развития процессов интеграции на основе теоретико-логического анализа с учетом стратегических направлений развития украинской экономики и мирового хозяйства. Вычислено прогнозные показатели для стран-членов группы ЕС и Украиной. Это позволило разработать прогнозные сценарии развития процессов интеграции стран-членов интеграционных процессов в перспективном периоде. На основе полученного прогноза сформирован стратегические позиции Украины и стран-членов ЕС в мировом интеграционном пространстве на три периода прогнозирования. Выводы: определены приоритетные сценарии развития интеграционных процессов этих стран-членов ЕС, а именно Czechia, Estonia, Latvia, Lithuania, Poland и Ukraine свидетельствуют о положительной перспективе сотрудничества ЕС с Украиной в аспекте международной интеграции.

Ключевые слова: страны ЕС, глобализация, интеграционные процессы, международные экономические отношения, сценарии развития интеграции, анализ факторов, кривые роста, прогнозирование.

\section{References}

1. Dubrov, A.M. \& Mhitarjan, V.S. \& Troshin, L.I. (2000). Mnogomernye statisticheskie metody [Multivariate statistical methods]. Moskow: Finansy i statistika (in Russian).

2. Maljarets, L. M. (2006). Vimirjuvannja oznak obyektiv v ekonomici: metodologija ta praktika: naukove vidannja [Measurement of features of objects in the economy: methodology and practice : scientific publication]. Harkiv : HNEU (in Ukraine).

3. Ponomarenko, V.S. \& Maljarets, L. M. (2009). Analiz danih u doslidzhennjah socialno-ekonomichnih sistem: monografija [Analysis of data in studies of socio-economic systems: monuscript]. Harkiv : HNEU (in Ukraine).

4. Babenko, V., Pasmor, M., Pankova, Ju., Sidorov, M. (2017). The place and perspectives of Ukraine in international integration space. Problems and Perspectives in Management, Vol. 15, Issue 1, pp. 80-92. doi: $10.21511 / \mathrm{ppm} .15(1) .2017 .08$

5. Dluhopolskyi, O., Zatonatska, T., Lvova, I., Klapkiv, Y. (2019). Regulations for returning labour migrants to Ukraine: international background and national limitations. Comparative Economic Research. Central and Eastern Europe, Vol.22(3), 45-64.

6. United Nations Conference on Trade and Development Available at: https://unctad.org/en/Pages/statistics.aspx (accessed (03.03.2020))

7. Michurina, O.Ju. (2014). Prognozirovanie rezultatov integracionnyh processov na osnove imitacionnogo modelirovanija [Predicting the outcome of integration processes on the basis of simulation modeling]. Astrahan: Vestnik Astrahanovskogo gosudarstvennogo tehnicheskogo universiteta. Ser.: Ekonomika (in Russian).

8. Anisimov, A.M. \& Shirov, A.A. (2013). Problemy razrabotki scenariev ocenki dolgosrochnyh jeffektov integracionnyh processov na postsovetskom prostranstve [Scripting problems assessing long-term effects of the integration processes on the post-Soviet space]. Problemy prognozirovanija (in Russian).

9. Burganova, I.N. (2015). Scenarii mezhgosudarstvennoj integracii na postsovetskom prostranstve v ramkah SNG [Interstate integration scenarios in the post within the CIS]. S.-Petersburg: Izvesa Izvestija Rossijskogo gosudarstvennogo pedagogicheskogo universiteta im. A.I. Gercena (in Russian).

10. BRICS Joint Statistical Publication: 2019; Brazil, Russia, India, China, South Africa. (2019). Rosstat, Moscow: «Statistics of Russia».

11. Schwab, K. \&. Sala-i-Martín, X (Eds.). (2015). The Global Competitiveness Report 2014-2015. Geneva: World Economic Forum.

12. Mirovoj Atlas Dannyh [World Data Atlas]. (2015). Moscow: Mirovaja i regionalnaja statistika, nacionalnye dannye, karty i rejtingi. (in Russian).

13. Babenko V., Biletska Y., Pelyak H. (2019). Ukraine-EU: economic integration strategy. Geopolitics under Globalization, 3(1), 12-23. doi:https://doi.org/10.21511/gg.03(1).2020.02

14. Tovarna struktura zovnishnoyi torgivli Ukrayini: Statistichna informacija [Commodity structure of foreign trade of Ukraine: Statistical information]. (2019). Kiev: State. Statistics Service of Ukraine. (in Ukraine). 


\section{Лiтература}

1. Аубров А.М., Мхитарян В.С., Трошин А.И. Многомерные статистические метоgы. М.: Финансы и статистика, 2003. 352 с.

2. Малярець Л.М. Вимірювання ознак об'єктів в економіці: метоgологія та практика. Х.: ХНЕУ, 2006. 382 с.

3. Пономаренко В.С., Малярець А.М. Аналіз gаних у gосліgженнях соціально-економічних систем: монографія. Х.: ХНЕУ, 2009. 507 с.

4. Babenko V., Pasmor M., Pankova Ju., Sidorov M. The place and perspectives of Ukraine in international integration space. Problems and Perspectives in Management. 2017. Vol. 15, Issue 1. Pp. 80-92. doi 10.21511/ppm.15(1).2017.08

5. Dluhopolskyi O., Zatonatska T., Lvova I., Klapkiv Y. Regulations for returning labour migrants to Ukraine: international background and national limitations. Comparative Economic Research. Central and Eastern Europe. 2019. Vol.22 (3). P. 45-64.

6. United Nations Conference on Trade and Development. URL: https://unctad.org/en/Pages/statistics.aspx (accessed 03.03.2020)

7. Мичурина О.Ю. Прогнозирование результатов интеграционных процессов на основе имитационного моделирования. Вестник Астраханского госуяарственного технического университета. Серия "Экономика». 2011. № 2. URL: https://cyberleninka.ru/article/n/prognozirovanie-rezultatov-integratsionnyh-protsessov-na-osnoveimitatsionnogo-modelirovaniya/viewer

8. Анисимов А.М., Широв А.А. Проблемы разработки сценариев оценки долгосрочных эффректов интеграционных процессов на постсоветском пространстве. Проблемы прогнозирования. 2013. URL: https://cyberleninka.ru/article/n/problemy-razrabotki-stsenariev-otsenki-dolgosrochnyh-effektov-integratsionnyhprotsessov-na-postsovetskom-prostranstve/viewer

9. Бурганова И.Н. Сценарии межгосударственной интеграции на постсоветсокм пространстве в рамках СНГ. Известия Российского государственного педагогического университета им. А.И. Герцена. 2015. URL: https://cyberleninka.ru/article/n/stsenarii-mezhgosudarstvennoy-integratsii-na-postsovetskom-prostranstve-vramkah-sng/viewer

10. BRICS Joint Statistical Publication: 2015; Brazil, Russia, India, China, South Africa. Rosstat. Moscow: «Statistics of Russia».

11. Schwab, K. \&. Sala-i-Martín, X (Eds.). The Global Competitiveness Report 2014-2015. Geneva: World Economic Forum. 2015.

12. Мировой Атлас Аанных. Москва: Мировая и региональная статистика, национальные данные, карты и рейтинги. 2015. URL: https://knoema.ru/atlas

13. Babenko V., Biletska Y., Pelyak H. Ukraine-EU: economic integration strategy. Geopolitics under Globalization, 2019, 3(1), 12-23. doi:https://doi.org/10.21511/gg.03(1).2020.02

14. Товарна структура зовнішньої торгівлі України. Державна служба статистики України. URL: http://www.ukrstat.gov.ua/ 